\title{
ANALISIS FAKTOR-FAKTOR KEUANGAN YANG MEMPENGARUHI KINERJA KEUANGAN PADA PERUSAHAAN MANUFAKTUR YANG TERDAFTAR DI BEI
}

\author{
Rima D. Mangundap \\ Herman Karamoy \\ Stanly Alexander
}

\author{
Fakultas Ekonomi Dan Bisnis Jurusan Akuntansi \\ Universitas Sam Ratulangi Manado \\ email : th3a.mangundap@yahoo.com
}

\begin{abstract}
ABSTRAK
Perusahaan sebagai salah satu bentuk organisasi pada umumnya memiliki tujuan tertentu yang ingin dicapai dalam usaha untuk memenuhi kepentingan para anggotanya. Keberhasilan dalam mencapai tujuan perusahaan merupakan prestasi manajemen. Penilaian prestasi atau kinerja suatu perusahaan diukur karena dapat dipakai sebagai dasar pengambilan keputusan baik pihak internal maupun eksternal.Tujuan diadakannya penelitian ini adalah untuk mengetahui Apakah struktur aktiva, rasio hutang, dan struktur modal berpengaruh terhadap kinerja keuangan perusahaan baik secara simultan maupun parsial. Metode penelitian yang digunakan dalam penelitian ini adalah persamaan regresi linier berganda.Dalam pengujian secara simultan diperoleh hasil bahwa faktor-faktor keuangan memiliki pengaruh signifikan terhadap kinerja keuangan perusahaan. Hal ini ditunjukan oleh nilai $\mathrm{F}$ hitung lebih besar dari nilai $\mathrm{F}$ tabel serta nilai signifikan lebih kecil dari ukuran signifikan. Selanjutnya pada pengujian secara parsial dari ketiga variable yang diuji hanya struktur modal yang memiliki pengaruh signifikan terhadap kinerja keuangan perusahaan.
\end{abstract}

Kata kunci : kinerja keuangan,aktiva, kewajiban dan modal

\begin{abstract}
Companies as a form of organization in general has a specific goal to be achieved in an effort to meet the interests of its members. Success in achieving the company's goal is performance management. Performance appraisal or performance of a company is measured because it can be used as the basis for decision making both internally and eksternal.Tujuan of this study was to determine Is asset structure, debt ratios, and capital structure affect the financial performance of companies either simultaneously or partially. The method used in this study is the linear regression equation berganda.Dalam simultaneous testing result that financial factors have a significant influence on the financial performance of the company. This is evidenced by calculated $F$ value is greater than the value of $F$ table and significant values significantly smaller than the size. Subsequently the partial test of the three variables tested only a capital structure that has a significant influence on the financial performance of the company.
\end{abstract}

Keywords :financial performance, assets, obligation and capital 


\section{Latar Belakang}

\section{PENDAHULUAN}

Kondisi dunia yang tidak menentu seperti terjadinya global warming, kemiskinan yang semakin meningkat, memburuknya kesehatan masyarakat serta tuntutan sosial kepada perusahaan, memicu perusahaan dalam mengungkapkan tanggungjawab sosial (sosial responsibility) perusahaan pada seluruh stakeholder yang terdiri dari karyawan, investor, pemerintah, masyarakat, konsumen dan pemasok, serta kelangsungan generasi penerus,karena itu muncul pula kesadaran untuk mengurangi dampak negatif ini dengan menggunakan pendekatan tanggungjawab sosial dan lingkungan atau dikenal dengan sebutan Corporate Social Responsibility (CSR), perusahaan tidak hanya mendapatkan keuntungan ekonomi, keuntungan sosial, tetapi keberlangsungan usaha tersebut dapat berlangsung dengan baik dan secara tidak langsung akan mencegah konflik yang merugikan dan meningkatkan kualitas masyarakat sekitar (termasuk karyawan, pemasok dan pelanggan) serta lingkungan yang menjadi pemangku kepentingan atau stakeholder. Contoh bentuk tanggungjawab itu bermacam-macam, mulai dari melakukan kegiatan yang dapat meningkatkan kesejahteraan masyarakat dan perbaikan lingkungan, pemberian beasiswa untuk anak tidak mampu, pemberian dana untuk pemeliharaan fasilitas umum, sumbangan untuk desa/fasilitas masyarakat yang bersifat sosial dan berguna untuk masyarakat banyak, khususnya masyarakat yang berada di sekitar perusahaan tersebut beroperasi.

Perusahaan sebagai salah satu bentuk organisasi pada umumnya memiliki tujuan tertentu yang ingin dicapai dalam usaha untuk memenuhi kepentingan para anggotanya. Suatu perusahaan yang berkembang dan cenderung menguasai pasar tentunya dituntut untuk senantiasa meningkatkan laba perusahaan dan pelayanan produksinya dengan sistem manajemen dan marketingnya, sehingga tetap mampu dan bertahan dalam persaingan global ekonomi dan bisnis baik lokal maupun internasional.

Kinerja perusahaan merupakan suatu gambaran tentang kondisi keuangan suatu perusahaan yang dianalisis dengan alat-alat analisis keuangan, sehingga dapat diketahui mengenai baik buruknya keadaan keuangan suatu perusahaan yang mencerminkan prestasi kerja dalam periode tertentu. Hal ini sangat penting agar sumber daya digunakan secara optimal dalam menghadapi perubahan lingkungan. Penilaian kinerja keuangan merupakan salah satu cara yang dapat dilakukan oleh pihak manajemen agar dapat memenuhi kewajibannya terhadap para penyandang dana dan juga untuk mencapai tujuan yang telah ditetapkan oleh perusahaan. Apalagi tidak dapat dipungkiri bahwa kemungkinan setiap perusahaan akan dilanda krisis moneter akibat dampak krisis moneter negara atau dunia menyebabkan perekonomian masyarakat mengalami keterpurukan.

\section{Tujuan Penelitian}

Tujuan penelitian adalah :

1. Untuk mengetahui pengaruh struktur aktiva, rasio hutang dan struktur modal terhadap kinerja keuangan perusahaan.

2. Untuk mengetahui pengaruh struktur aktiva, rasio hutang dan struktur modal secara parsial berpengaruh terhadap kinerja keuangan perusahaan.

\section{Konsep Akuntansi}

\section{TINJAUAN PUSTAKA}

Maulani (2010) menyatakan bahwa akuntansi adalah suatu proses mencatat, mengklasifikasi, meringkas, mengolah dan menyajikan data, transaksi serta kejadian yang berhubungan dengan keuangan sehingga dapat digunakan oleh orang yang menggunakannya dengan mudah dimengerti untuk pengambilan suatu keputusan serta tujuan lainnya. Proses untuk mencatat, mengklasifikasi, meringkas, mengolah, dan menyajikan setiap transaksi diatur di dalam standar akuntansi yang berbeda di setiap negara. Akuntansi digunakan di hampir seluruh kegiatan bisnis di seluruh dunia untuk mengambil keputusan sehingga disebut sebagai bahasa bisnis. Fungsi utama akuntansi adalah sebagai informasi keuangan suatu organisasi karena dari laporan akuntansi kita bisa melihat posisi keuangan suatu organisasi beserta perubahan yang terjadi di dalamnya. Akuntansi dibuat secara kualitatif dengan satuan 
ukuran uang. Informasi mengenai keuangan sangat dibutuhkan khususnya oleh pihak manajer/manajemen untuk membantu membuat keputusan suatu organisasi. Informasi keuangan yang akan membantu membuat keputusan berupa laporan keuangan.

Horngren dan Harrison (2007), mendefinisikan akuntansi adalah sistem informasi yang mengukur aktivitas bisnis, memproses data menjadi laporan dan mengkomunikasikan hasilnya kepada para pengambil keputusan.

\section{Peranan Akuntansi dalam Penyediaan Informasi}

Informasi akuntansi adalah data transaksi keuangan untuk suatu periode tertentu yang diikhtisarkan dalam bentuk laporan keuangan (financial statement). Pihak-pihak yang berkepentingan terhadap informasi akuntansi serta kegunaannya bagi pihak bersangkutan tersebut antara lain :

1. Pimpinan perusahaan

2. Pemilik perusahaan

3. Kreditor dan calon kreditor

4. Investor dan calon investor

5. Instansi pemerintah

6. Karyawan

\section{Konsep Laporan Keuangan}

Secara umum laporan keuangan adalah catatan informasi keuangan suatu perusahaan pada suatu periode akuntansi yang dapat digunakan untuk menggambarkan kinerja perusahaan tersebut. Laporan keuangan dibuat dengan maksud memberikan gambaran kemajuan (progress report) perusahaan secara periodik. Jadi laporan keuangan bersifat historis serta menyeluruh dan sebagai suatu progress report. Laporan keuangan terdiri dari data-data yang merupakan hasil dari kombinasi antara fakta yang telah dicatat, prinsip-prinsip dan kebiasaan-kebiasaan dalam akutansi serta pendapat pribadi. Fakta-fakta yang telah dicatat, laporan keuangan dibuat berdasarkan fakta dari catatan akutansi, pencatatan dari pospos ini merupakan catatan historis dari peristiwa yang telah terjadi dimasa lampau dan jumlah uang yang tercatat dinyatakan dalam harga pada waktu terjadinya peristiwa tersebut. Dengan sifat yang demikian maka laporan keuangan tidak dapat mencerminkan posisi keuangan dari suatu perusahaan dalam kondisi perekonomian paling akhir. Prinsip dan kebiasaan di dalam akutansi, data yang dicatat didasarkan pada prosedur maupun anggapan-anggapan tertentu yang merupakan prinsip-prinsip akutansi yang lazim, di dalam akutansi juga digunakan prinsip atau anggapan-anggapan yang melengkapi konvensi-konvensi atau kebiasaan yang digunakan antara lain : bahwa perusahaan akan tetap berjalan sebagai suatu yang going concern, konsep ini menganggap bahwa perusahaan akan berjalan terus, konsekwensinya bahwa jumlahjumlah yang tercantum dalam laporan merupakan nilai-nilai untuk perusahaan yang masih berjalan yang didasarkan pada nilai atau harga pada terjadinya peristiwa itu. Jadi jumlah uang yang tercantum dalam laporan bukanlah nilai realisasi jika aktiva tersebut dijual.

\section{Konsep Kinerja Dan Kinerja Keuangan}

Kamus Besar Bahasa Indonesia menyebutkan Kinerja adalah sesuatu yang dicapai, prestasi yang diperlihatkan, kemampuan kerja (tentang peralatan). Keuangan adalah seluk-beluk uang, urusan uang, keadaan uang. Perusahaan adalah kegiatan (pekerjaan dan sebagainya) yang diselenggarakan dengan peralatan atau dengan cara teratur dengan tujuan mencari keuntungan (dengan menghasilkan sesuatu, mengolah atau membuat barang-barang, berdagang, memberikan jasa, dan sebagainya), organisasi berbadan hukum yg mengadakan transaksi atau usaha. Dari definisi tersebut dapat disimpulkan bahwa Kinerja keuangan perusahaan adalah sesuatu yang dicapai/prestasi yang diperlihatkan mengenai keadaan keuangan oleh organisasi berbadan hukum yang mengadakan transaksi atau usaha. Kinerja perusahaan adalah suatu tampilan tentang kondisi financial perusahaan selama periode waktu tertentu. Untuk mengukur keberhasilan suatu perusahaan pada umumnya berfokus pada laporan keuangan disamping data-data non keuangan lain yang bersifat sabagai penunjang yang diukur dari laporan keuangan yang dikeluarkan secara periodik. 
Penilaian kinerja menurut Setyasih (2009) adalah penentuan efektivitas operasional, organisasi, dan karyawan berdasarkan sasaran, standar dan kriteria yang telah ditetapkan sebelumnya secara periodik. Ada dua macam kinerja, yakni kinerja opeasional dan kinerja keuangan. Kinerja operasional lebih ditekankan pada kepentingan internal perusahaan seperti kinerja cabang/divisi yang diukur dengan kecepatan dan kedisiplinan. Sedangkan kinerja keuangan lebih kepada evaluasi laporan keuangan perusahaan pada waktu dan jangka tertentu. Kinerja keuangan perusahaan dapat diukur dengan menggunakan analisis rasio keuangan untuk mengetahui keunggulan dari kekuatan perusahaan secara simultan dan mengoreksi kelemahan perusahaan. Dengan hal ini diharapakan menunjukkan hubungan suatu laporan keuangan finansial baik berupa neraca dan atau laporan laba rugi. Lebih lanjut, adapun rasio keuangan yang umum digunakan dalam pengukuran kinerja perusahaan adalah rasio leverage, rasio likuiditas, rasio aktivitas, dan rasio profitabilitas.

Pengukuran kinerja dapat digunakan untuk menekan perilaku yang tidak semestinya dan untuk merangsang serta menegakkan perilaku yang semestinya diinginkan, melalui umpan balik hasil kinerja pada waktunya serta pemberian penghargaan, baik yang bersifat intrinsik maupun ekstrinsik. Melalui pengukuran kinerja, manajemen puncak dapat memperoleh dasar yang obyektif untuk memberikan kompensasi sesuai dengan prestasi yang disumbangkan masing-masing pusat pertanggungjawaban kepada perusahaan secara keseluruhan. Semua ini diharapkan dapat memberikan motivasi dan rangsangan pada masing-masing bagian untuk bekerja lebih efektif dan efisien.secara umum $t$ ujuan pokok kinerja adalah untuk memotivasi karyawan dalam pencapaian sasaran organisasi dan dalam mematuhi standar perilaku yang telah ditetapkan sebelumnya, agar membuahkan hasil dan tindakan yang sesuai dengan tujuan organisasi.

\section{Laporan Keuangan Sebagai Alat Penilaian Kinerja Perusahaan}

Munawir (2010:5), pada umumnya laporan keuangan itu terdiri dari neraca dan perhitungan labarugi serta laporan perubahan ekuitas. Neraca menunjukkan/menggambarkan jumlah aset, kewajiban dan ekuitas dari suatu perusahaan pada tanggal tertentu. Kasmir (2008:7) berpendapat bahwa: Laporan keuangan adalah laporan yang menunjukkan kondisi keuangan perusahaan pada saat ini atau dalam suatu periode tertentu. Sedangkan perhitungan (laporan) laba-rugi memperlihatkan hasil-hasil yang telah dicapai oleh perusahaan serta beban yang terjadi selama periode tertentu, dan laporan perubahan ekuitas menunjukkan sumber dan penggunaan atau alasan-alasan yang menyebabkan perubahan ekuitas perusahaan. Adapun definisi dari Sutrisno (2007 : 9) laporan keuangan merupakan hasil akhir dari proses akuntansi yang meliputi dua laporan utama, yakni (1) Neraca dan (2) Laporan Laba-Rugi. Sedangkan Harahap (2009:105), laporan keuangan menggambarkan kondisi keuangan dan hasil usaha suatu perusahaan pada saat tertentu atau jangka waktu tertentu. Adapun jenis laporan keuangan yang lazim dikenal adalah neraca, laporan laba-rugi atau hasil usaha, laporan perubahan ekuitas, laporan arus kas, laporan posisi keuangan. Kieso dan Weygandt, (2007 : 5) yang dialih bahasakan oleh Herman Wibowo menyebutkan tentang jenis-jenis laporan keuangan adalah sebagai berikut :

"Laporan keuangan yang sering disajikan adalah neraca, laporan laba/rugi, laporan arus kas, laporan ekuitas pemilik atau pemegang saham".

Laporan keuangan merupakan gambaran dari suatu perusahaan pada waktu tertentu (biasanya ditunjukkan dalam periode atau siklus akuntansi), yang menunjukkan kondisi keuangan yang telah dicapai suatu perusahaan dalam periode tertentu. Dengan kata lain, laporan keuangan merupakan ringkasan dari suatu proses pencatatan, yaitu merupakan suatu ringkasan dari transaksi-transaksi keuangan yang terjadi selama tahun buku yang bersangkutan. Laporan keuangan yang lengkap biasanya meliputi neraca, laporan laba rugi, laporan perubahan posisi keuangan (yang dapat disajikan dalam berbagai cara seperti, misalnya sebagai laporan arus kas atau laporan arus dana), catatan dan laporan lain serta materi penjelasan yang merupakan bagian integral dari laporan keuangan. 
Penelitian Terdahulu

Tabel 1. Penelitian Terdahulu

\begin{tabular}{|c|c|c|c|c|c|c|}
\hline $\begin{array}{l}\text { Nama } \\
\text { Peneliti/ } \\
\text { Tahun }\end{array}$ & Judul & Tujuan & $\begin{array}{l}\text { Metode } \\
\text { Penelitian }\end{array}$ & $\begin{array}{l}\text { Hasil } \\
\text { Penelitian }\end{array}$ & Persamaan & Perbedaan \\
\hline $\begin{array}{l}\text { Noor/ } \\
2011\end{array}$ & $\begin{array}{l}\text { Analisis } \\
\text { faktor-faktor } \\
\text { yang } \\
\text { mempengaruhi } \\
\text { kinerja } \\
\text { keuangan } \\
\text { perusahaan } \\
\text { telekomunikasi } \\
\text { go public di } \\
\text { Bursa Efek } \\
\text { Indonesia }\end{array}$ & $\begin{array}{l}\text { Untuk mengukur } \\
\text { sejauh mana } \\
\text { efektifitas } \\
\text { operasi } \\
\text { perusahaan } \\
\text { dalam } \\
\text { pencapaian } \\
\text { tujuannya dan } \\
\text { menilai kinerja } \\
\text { perusahaan } \\
\text { dalam } \\
\text { menggunakan } \\
\text { laporan keuangan } \\
\text { perusahaan yang } \\
\text { diperbandingkan, } \\
\text { termasuk data } \\
\text { tentang penambahan- } \\
\text { penambahan } \\
\text { yang terjadi } \\
\text { dalam jumlah } \\
\text { rupiah, presentasi } \\
\text { dan tren_nya }\end{array}$ & kuantitatif & $\begin{array}{l}\text { Sistem kinerja } \\
\text { keuangan } \\
\text { perusahaan } \\
\text { telekomunikasi } \\
\text { yang go public } \\
\text { dikatakan } \\
\text { efektif }\end{array}$ & $\begin{array}{l}\text { Penelitian } \\
\text { sebelumnya } \\
\text { menggunakan } \\
\text { penelitian } \\
\text { terhadap } \\
\text { faktor yang } \\
\text { sama yaitu } \\
\text { kinerja } \\
\text { keuangan } \\
\text { perusahaan }\end{array}$ & $\begin{array}{l}\text { Peneliti } \\
\text { sebelumnya } \\
\text { Dilakukan } \\
\text { pada } \\
\text { perusahaan } \\
\text { telekomunikasi } \\
\text { yang go public } \\
\text { di Bursa Efek } \\
\text { Indonesia }\end{array}$ \\
\hline $\begin{array}{l}\text { Efandiana/ } \\
2011\end{array}$ & $\begin{array}{l}\text { Analisis } \\
\text { faktor-faktor } \\
\text { yang } \\
\text { berpengaruh } \\
\text { terhadap } \\
\text { kinerja } \\
\text { intellectual } \\
\text { capital pada } \\
\text { perusahaan } \\
\text { manufaktur } \\
\text { yang terdaftar } \\
\text { di Bursa Efek } \\
\text { Indonesia (BEI }\end{array}$ & $\begin{array}{l}\text { Untuk menguji } \\
\text { pengaruh Capital } \\
\text { Adequacy Ratio } \\
\text { (CAR), Non } \\
\text { Performing Loan } \\
\text { (NPL), Bopo } \\
\text { (Biaya } \\
\text { Operasional/ } \\
\text { Pendapatan } \\
\text { Operasional } \\
\text { bopo, Loan to } \\
\text { Deposit Ratio } \\
\text { (LDR), dan Net } \\
\text { Interest Margin } \\
\text { (NIM) terhadap } \\
\text { Return On Assets } \\
\text { (ROA) }\end{array}$ & Kuantitatif & $\begin{array}{l}\text { Variabel NIM, } \\
\text { LDR, NPL dan } \\
\text { BOPO } \\
\text { memberikan } \\
\text { pengaruh } \\
\text { terbesar } \\
\text { terhadap } \\
\text { Return On } \\
\text { Assets (ROA). }\end{array}$ & $\begin{array}{l}\text { Penelitian } \\
\text { sebelumnya } \\
\text { menggunakan } \\
\text { tempat yang } \\
\text { sama yaitu } \\
\text { Perusahaan } \\
\text { Manufaktur } \\
\text { yang terdaftar } \\
\text { di Bursa Efek } \\
\text { Indonesia }\end{array}$ & $\begin{array}{l}\text { Penelitian } \\
\text { sebelumnya } \\
\text { menggunakan } \\
\text { faktor kinerja } \\
\text { intellectual } \\
\text { capital. }\end{array}$ \\
\hline
\end{tabular}

\section{Jenis Penelitian}

\section{METODOLOGI PENELITIAN}

Penelitian ini merupakan penelitian kuantitatif. Penelitian ini menggambarkan data yang diperoleh dan menganalisis data yang ada. Data kuantitatif, merupakan data yang disajikan dalam bentuk skala numeric (angka). Dalam melaksankan analisis dan pembahasan terhadap masalah dalam penelitian 
ini menggunakan data kuantitatif berupa laporan keuangan perusahaan manufaktur yang diambil dari Bursa Efek Indonesia(BEI).

\section{Sumber Data}

Sumber data yang digunakan dalam penelitian ini adalah data sekunder, dimana laporan keuangan perusahaan publik yang terdaftar di Bursa Efek Indonesia selama tahun 2007-2009 dapat diakses lewat www.idx.co.id ataupun diperoleh di Bursa Efek Indonesia cabang Manado. Selain itu penulis juga memperoleh tambahan data dari jurnal dan literatur lain.

\section{Teknik Pengumpulan Data}

Untuk memperoleh data yang berhubungan dengan penelitian ini maka penulis menggunakan metode pengumpulan data sebagai berikut.

1. Pengumpulan informasi dengan mencari buku-buku diperpustakaan yang berhubungan erat dengan masalah yang akan dibahas atau diteliti untuk digunakan sebagai dasar teori yang melengkapi proses penyusunan skripsi ini;

2. Media elektronik, yaitu dengan mengakses data lewat internet untuk melengkapi data yang dibutuhkan.

3. Pengambilan data secara langsung di Bursa Efek Indonesia cabang Manado.

\section{Hasil Penelitian}

\section{HASIL PENELITIAN DAN PEMBAHASAN}

1. Deskripsi Populasi dan Sampel Penelitian

Jumlah populasi perusahaan publik yang terdaftar di Bursa Efek Indonesia selama periode pengamatan 2007-2009 adalah 295 perusahaan yang terbagi dalam 12 kelompok usaha, yang dapat dilihat pada tabel 2 .

Table 2. Jumlah Perusahaan Publik di BEI Tahun 2007-2009

\begin{tabular}{|c|c|c|}
\hline No & Jenis Usaha & $\begin{array}{c}\text { Jumlah } \\
\text { Perusahaan }\end{array}$ \\
\hline 1 & Agryculture forestry and fishing & 4 \\
\hline 2 & Animal food and hubandary & 5 \\
\hline 3 & Mining and mining service & 8 \\
\hline 4 & Consruction & 2 \\
\hline 5 & Manufacturing & 129 \\
\hline 6 & Transportation service & 10 \\
\hline 7 & Telecomunications & 5 \\
\hline 8 & Wholesale and retail trade & 16 \\
\hline 9 & Banking, credit agencies othe than bank, securities insurances and real estate & 89 \\
\hline 10 & Hotel and travel services & 6 \\
\hline 11 & Holding and other investment companies & 3 \\
\hline \multirow[t]{2}{*}{12} & Others & 18 \\
\hline & Total Perusahaan & 295 \\
\hline
\end{tabular}

Sumber: Indonesian Capital Market Directory 2006-2009

Selanjutnya, dari berbagai jenis bidang usaha yang terdaftar di BEI maka ditentukan bidang usaha yang akan dijadikan objek penelitian adalah bidang usaha manufaktur yang terdiri dari 129 perusahaan yang dapat kita lihat pada table 3 . 
Table 3. Jumlah Perusahaan Manufaktur di BEI tahun 2006-2009

\begin{tabular}{|c|c|c|}
\hline No. & Jenis Usaha & $\begin{array}{c}\text { Jumlah } \\
\text { Perusahaan }\end{array}$ \\
\hline 1. & Food and Beverages & 17 \\
\hline 2. & Tobacco Manufacturers & 3 \\
\hline 3. & Textile Mill Products & 8 \\
\hline 4. & Apparel and Other Textile Products & 11 \\
\hline 5. & Lumber and Wood Products & 3 \\
\hline 6. & Paper and Allied Products & 5 \\
\hline 7. & Chemical and Allied Products & 8 \\
\hline 8. & Adhesive & 4 \\
\hline 9. & Plastic and Glass Products & 14 \\
\hline 10. & Cement & 3 \\
\hline 11. & Metal and Allied Products & 11 \\
\hline 12. & Fabricated Metal & 2 \\
\hline 13. & Stone, Clay, Glass and Concrete Products & 5 \\
\hline 14. & Cables & 6 \\
\hline 15. & Electronic and Office Equipment & 3 \\
\hline 16. & Automotive and Allied Products & 18 \\
\hline 17. & Photographic Equipment & 3 \\
\hline 18. & Pharmaceuticals & 9 \\
\hline 19. & Consumer Goods & 3 \\
\hline \multicolumn{2}{|r|}{ Total Perusahaan } & 136 \\
\hline
\end{tabular}

Sumber: Indonesian Capital Market Directory 2006-2009

Dari populasi yang tunjukkan tabel 3 dalam penelitian ini, sampel dipilih dengan metode purposive sampling yang mana perusahaan terpilih adalah perusahaan yang memenuhi criteria yang tetapkan dari segi periode pelaporan. Berdasarkan proses seleksi ditetapkan sebanyak 20 perusahaan manufaktur yang akan dijadikan sampel dengan periode pengamatan 3 tahun. 20 perusahaan yang terpilih menjadi sampel penelitian tersebut dipaparkan pada tabel 4.

Tabel 4. Daftar Perusahaan Manufaktur Terpilih

\begin{tabular}{lll}
\hline NO & KODE & \\
\hline 1 & ADES & PT. ADES WATER INDONESIA, Tbk \\
2 & ULTJ & PT. ULTRA JAYA MILK, Tbk \\
3 & SKLT & PT. SEKAR LAUT, Tbk \\
4 & MYOR & PT. MAYORA INDAH, Tbk \\
5 & KAEF & PT. KIMIA FARMA, Tbk \\
6 & FAST & PT. FAST FOOD, Tbk \\
7 & DAVO & PT. DAVO MAS ABADI, Tbk \\
8 & CEKA & CAHAYA KALBAR, Tbk \\
9 & CLPI & PT. COLOR PACK INDONESIA, Tbk \\
10 & INTP & INDOCEMENT TUNGGAL PERKASA, Tbk \\
11 & EKAD & EKADHARMA INTERNASIONAL, Tbk \\
12 & HDTX & PANASIA INDOSYTEC, Tbk \\
13 & KLBF & KALBE FARMA, Tbk \\
14 & MRAT & MUSTIKA RATU, Tbk \\
15 & HEXA & HEXINDO ADIPERKASA, Tbk \\
16 & TIRA & TIRA AUSTENITE, Tbk \\
17 & TLBA & TUNAS BARU LAMPUNG, Tbk \\
18 & PSDN & PRASIDHA ANEKA NIAGA, Tbk \\
19 & SMGR & SEMEN GRESIK (PERSERO), Tbk \\
20 & STTP & SIANTAR TOP, Tbk \\
\hline
\end{tabular}




\section{Pembahasan}

1. Pengaruh Struktur Aktiva terhadap kinerja keuangan pada perusahaan manufaktur yang terdaftar di Bursa Efek Indonesia

Berdasarkan hasil pengujian, secara keseluruhan diperoleh koefisien regresi struktur aktiva yang menunjukkan tanda negatif. Ini berarti peningkatan nilai struktur aktiva tidak akan mendorong peningkatan kinerja keuangan. Begitu pula sebaliknya, penurunan nilai struktur aktiva tidak akan mendorong penurunan kinerja keuangan. Berdasarkan hasil uji t menunjukkan bahwa bahwa nilai signifikansi t-hitung lebih besar dibandingkan 0,05. Dengan demikian, pengaruh struktur aktiva terhadap kinerja keuangan adalah tidak signifikan secara statistik. Pengujian koefisien dan berdasarkan hasil uji t ini secara keseluruhan menunjukkan bahwa tidak terdapat pengaruh signifikan antara laba akuntansi terhadap kinerja keuangan.

Dengan demikian hipotesis pertama yang menyatakan bahwa strukur aktiva mempunyai pengaruh positif dan signifikan terhadap kinerja keuangan tidak terbukti.

2. Pengaruh Rasio Hutang terhadap kinerja keuangan pada perusahaan manufaktur yang terdaftar di Bursa Efek Indonesia

Berdasarkan hasil pengujian, secara keseluruhan diperoleh koefisien regresi rasio hutang yang menunjukkan tanda negatif, ini berarti peningkatan nilai rasio hutang tidak akan mendorong peningkatan kinerja keuangan. Begitu pula sebaliknya, penurunan nilai rasio hutang tidak akan mendorong penurunan kinerja keuangan.

Berdasarkan hasil uji t menunjukkan bahwa bahwa nilai signifikansi t-hitung lebih besar dibandingkan 0,05. Dengan demikian, pengaruh rasio hutang terhadap kinerja keuangan adalah tidak signifikan secara statistik. Pengujian koefisien dan berdasarkan hasil uji t ini secara keseluruhan menunjukkan bahwa tidak terdapat pengaruh dengan arah positif dan signifikan antara rasio hutang terhadap kinerja keuangan. Dengan demikian hipotesis kedua yang menyatakan bahwa rasio hutang mempunyai pengaruh signifikan terhadap kinerja keuangan tidak terbukti.

3. Pengaruh Struktur Modal terhadap kinerja keuangan pada perusahaan manufaktur yang terdaftar di Bursa Efek Indonesia

Berdasarkan hasil pengujian, secara keseluruhan diperoleh koefisien regresi struktur modal yang menunjukkan tanda positif, ini berarti peningkatan nilai struktur modal akan mendorong peningkatan kinerja keuangan. Begitu pula sebaliknya, penurunan nilai struktur modal akan mendorong penurunan kinerja keuangan.

Berdasarkan hasil uji $\mathrm{t}$ menunjukkan bahwa bahwa nilai signifikansi t-hitung lebih kecil dibandingkan 0,05. Dengan demikian, secara statistik struktur modal mempunyai pengaruh signifikan terhadap kinerja keuangan. Pengujian koefisien dan berdasarkan hasil uji t ini secara keseluruhan menunjukkan bahwa terdapat pengaruh dengan arah positif dan signifikan antara struktur modal terhadap kinerja keuangan. Dengan demikian hipotesis ketiga yang menyatakan bahwa rasio struktur modal mempunyai pengaruh signifikan terhadap kinerja keuangan terbukti.

4. Pengaruh Struktur Aktiva, Rasio Hutang dan Struktur Modal terhadap kinerja keuangan pada perusahaan manufaktur yang terdaftar di Bursa Efek Indonesia.

Berdasarkan hasil analisis data program SPSS yang dilihat dari Uji F, menunjukkan bahwa struktur aktiva, rasio hutang dan struktur modal secara bersama-sama mempunyai pengaruh signifikan terhadap kinerja keuangan.

\section{Kesimpulan}

\section{PENUTUP}

Penelitian ini bertujuan mengetahui faktor-faktor keuangan yang mempengaruhi kinerja keuangan perusahaan manufaktur yang terdaftar di bursa efek indonesia. Berdasarkan hasil pembahasan pada bab sebelumnya, maka dapat ditarik kesimpulan sebagai Berikut :

1. Dalam pengujian secara parsial koefisien regresi struktur aktiva menunjukkan tanda negatif. Ini berarti peningkatan maupun Penurunan nilai struktur aktiva tidak berpengaruh terhadap kinerja keuangan perusahaan. 
2. Dalam pengujian secara parsial koefisien regresi struktur hutang menunjukkan tanda negatif. Ini berarti peningkatan maupun Penurunan nilai struktur hutang tidak memiliki pengaruh terhadap kinerja keuangan perusahaan.

3. Dalam Pengujian Secara parsial koefisien regresi struktur modal yang menunjukkan tanda positif. Ini berarti peningkatan maupun penurunan nilai struktur modal berpengaruh terhadap kinerja keuangan. Hal ini disebabkan oleh nilai rata-rata struktur modal pada keseluruhan perusahaan yang dijadikan sampel penelitian lebih dominan dari pada nilai rata-rata struktur aktiva dan rasio hutang.

4. Secara simultan faktor-faktor keuangan memiliki pengaruh signifikan terhadap kinerja keuangan perusahaan

\section{Saran}

Berdasarkan kesimpulan yang telah ditarik dari hasil analisis dan pembahasan, maka dapat disarankan beberapa hal sebagai berikut:

1. Secara akademis, penelitian ini diharapkan dapat meng-generalisasi hasil penelitian berkaitan dengan topik yang sama. Selain itu, penelitian ini juga dapat dikembangkan dengan memperpanjang periode penelitian dan memperbanyak variabel yang diteliti.

2. Bagi pihak manajemen perusahaan, dianggap perlu untuk melakukan pengendalian atas setiap aspek yang menjadi pendukung keberlangsungan hidup suatu perusahaan dan memanfaatkan setiap peluang-peluang yang ada untuk memperoleh dan meningkatkan laba atas usaha yang bertujuan agar perusahaan mampu bertahan dalam persaingan bisnis sejenis atau bisnis yang setaranya.

\section{DAFTAR PUSTAKA}

Efandiana, Ludita. 2011. analisis faktor-faktor yang berpengaruh terhadap kinerja intellectual capital pada perusahaan manufaktur yang terdaftar di Bursa Efek Indonesia. Skripsi. Universitas Dipenogoro Semarang. Semarang.

Harahap. 2009. analisis laporan keuangan. Blogspot. Jakarta http://fadhilanalisis.blogspot.com/2011/10/analisis-laporan-keuangan.html. di akses 30 Oktober 2013

Horngren, Charles., Harrison, Walter. 2007. pengertian akuntansi dari beberapa para ahli. Blogspot. Jakarta http://pengertianakuntansimenurut10paraahli.blogspot.com/2013/04/v/behaviorurldefaultvmlo.html. diakses 29 Oktober 2013

Kasmir. 2008. Analisis Laporan Keuangan, Edisi pertama. Rajawali Pers. Jakarta.

Kieso, Donald., Weygandt, Jerry. 2007. Pengantar akuntansi. Salemba empat. Jakarta

Maulani, Wahyu. 2010. pengertian dan penjelasan dasar akuntansi-definisi, arti, fungsi dan kegunaanbelajar ilmu akuntansi/accounting.organisasi.org.blogdetik. Jakarta http://wahyumaulani.blogdetik.com/ diakses 29 oktober 2013.

Munawir. 2010. analisis laporan keuangan.blogspot. yogyakarta http://fadhilanalisis.blogspot.com/2011/10/analisis-laporan-keuangan.html. diakses 30 Oktober $\underline{2013}$

Noor, Syafrudin, Akhmad. 2011. analisis faktor-faktor yang mempengaruhi kinerja keuangan perusahaan telekomunikasi yang go public di Bursa Efek Indonesia. Jurnal volume 12 no 1. Universitas Artakusuma Pangkalan Bun. Pangkalan Bun.

Setyasih. 2009. analisis perbandingan kinerja keuangan perusahaan sebelum dan setelah merger dan akuisi pada perusahaan manufaktur di BEI tahun 2003-2007. Skripsi. Universitas Diponegoro. Semarang.

Sutrisno. 2007. Manajemen Keuangan, Teori, Konsep dan Aplikasi. EKPNISIA, Fakultas Ekonomi UII. Yogyakarta. 